\title{
Effect of breed, gender, housing system and dietary crude protein content on performance of finishing beef cattle fed maize-silage-based diets
}

\author{
D. T. Juniper ${ }^{1 \dagger}$, M. J. Bryant ${ }^{1}$, D. E. Beever ${ }^{1 \neq}$ and A. V. Fisher ${ }^{2}$ \\ ${ }^{1}$ Department of Agriculture, University of Reading, Earley Gate, Reading RG6 6AR, UK; ${ }^{2}$ Division of Farm Animal Science, Department of Clinical Veterinary Science, \\ University of Bristol, Langford, Bristol BS40 5DU, UK
}

(Received 30 June 2006; Accepted 31 January 2007)

Maize silage-based diets with three dietary crude protein (CP) supplements were offered to 96 finishing cattle of contrasting breed (Holstein Friesian (HF) v. Simmental $\times$ HF (SHF)) and gender (bull v. steer) housed in two types of feeding system (group fed v. individually fed). The three protein supplements differed either in CP or protein degradability (degradable (LUDP) v. rumen undegradable (HUDP)) and provided CP concentrations of 142 (Con), 175 (LUDP) and 179 (HUDP) g/kg dry matter (DM) respectively, with ratios of degradable to undegradable of 3.0, 1.4 and 0.9:1 for diets Con, LUDP and HUDP, respectively. DM intakes were marginally higher $(\mathrm{P}=0.102)$ for LUDP when compared with Con and HUDP. Rates of daily live-weight gain (DLWG) were higher $(\mathrm{P}=0.005)$ in LUDP and HUDP when compared with Con. HF had higher DM intakes than SHF although this did not result in any improvement in HF DLWG. Bulls had significantly better DM intakes, DLWG and feed conversion efficiency than steers. Conformation scores were better in SHF than HF $(\mathrm{P}<0.001)$ and fat scores lower in bulls than steers $(\mathrm{P}<0.001)$. There was a number of first order interactions established between dietary treatment, breed, gender and housing system with respect to rates of gain and carcass fat scores.

Keywords: beef cattle, breed, crude protein, maize silage

\section{Introduction}

The low crude protein (CP) content of maize silage necessitates the provision of supplementary nitrogen $(\mathrm{N})$ for beef cattle fed maize-silage-based diets. Nitrogen supplementation of maize silage has been associated with increased intakes (Wilkinson et al., 1973) and improved rates of weight gain (Thomas et al., 1975), when compared with unsupplemented maize silage. However, the response to supplementary $\mathrm{N}$ can be dependent upon the $\mathrm{N}$ source as well as the physiological age of the animal (Bergen and Merkel, 1991).

The protein supplement chosen for maize silage diets can alter the overall nutritive value of the ration. Cottrill and Osbourne (1977) examined the ratio of protein $\mathrm{N}$ to non-protein N (NPN) in the supplements of maize silage fed to beef cattle and reported increased daily live-weight gain (LWG) when the contribution of fish meal was increased from 20 to $35 \mathrm{~g} \mathrm{CP}$ per $\mathrm{kg}$ dry-matter intake

\footnotetext{
${ }^{\dagger}$ E-mail: d.t.juniper@reading.ac.uk

‡Present address; Richard Keenan \& Co., Borris, Co. Carlow, Ireland.
}

(DMI), with no further improvement noted at higher rates of fish-meal supplementation. Subsequent metabolic studies by Cottrill et al. (1982) demonstrated that the improved LWG of cattle was the result of increased flows of both total $\mathrm{N}$ and total amino acids to the duodenum, associated with increased efficiency of microbial protein synthesis.

Different genotypes and genders have different requirements for metabolisable protein (MP). The Agricultural Research Council (ARC, 1980) provides correction factors for genotype and gender; entire males have a greater capacity for lean tissue deposition than steers and consequently are more sensitive to the effects of dietary protein restriction than steers. Equally, Holstein-Friesians, when compared with Simmentals, have quite different growth characteristics, due to the selection of milk production traits that have resulted in a comparatively large-framed animal. Paradoxically, both Simmentals and Holstein-Friesians are classed as late-maturing breeds and on theoretical grounds share similar nutrient requirements for maintenance and growth. 
The aims of this study were four-fold. Firstly to confirm whether additional protein supplementation of maize silage can improve overall performance of finishing cattle. Secondly, to ascertain whether the type of protein supplementation, rumen degradable (RDP) v. undegradable (UDP), can influence animal performance. Thirdly to investigate the responses to increasing the CP content of maize silagebased rations by two contrasting genders, namely bulls and steers, and two contrasting breeds, Simmentals and Holstein-Friesians, to determine the optimum level of protein supplementation to achieve maximal growth rates. Finally to compare the actual performance of cattle from this study to those predicted from established ARC equations.

\section{Material and methods}

\section{Crop management and harvest}

The maize crop was precision-drilled at a rate of 108000 seeds per ha on 5 and 10 May into three fields $\left(51^{\circ} .24^{\prime} \mathrm{N}\right.$ $0^{\circ} .56^{\prime} \mathrm{W}$ ) of similar soil type (loam over clay) in which maize had been grown during the previous year. At drilling the crop received $125 \mathrm{~kg} / \mathrm{ha}$ of mono-ammonium phosphate. None of the fields received any farmyard manure or slurry applications, but $60 \mathrm{~kg} / \mathrm{ha}$ inorganic fertiliser was applied on 21 June. Herbicide treatments of Atrazine ${ }^{\circledR}$ and Bromotril $®$ (2.0 and $0.6 \mathrm{l} / \mathrm{ha}$ respectively) were applied on the 16 June to control the growth of broad-leafed and grassy weeds.

The maize silage comprised of a mixture of two varieties, Hudson and Advance (Advanta Seeds UK, Lincs). Harvest started on the 26 October using a self-propelled John Deere 6810 forage harvester fitted with a conventional four-row header and kernel processor. A total of 17 ha was harvested, ensiled immediately without any additive, and rolled thoroughly before being sheeted and covered with tyres to ensure exclusion of air.

\section{Dietary treatments}

Three diets, comprising of maize silage and one of three protein supplements (Table 1), provided as a total mixed ration (TMR) (average forage to concentrate ratio 82:18)

Table 1 Ingredient composition of experimental concentrates CON, LUDP and HUDP (kg/t fresh weight)

\begin{tabular}{|c|c|c|c|}
\hline & \multicolumn{3}{|c|}{ Diet } \\
\hline & CON & LUDP & HUDP \\
\hline Wheat & 606 & - & - \\
\hline Peas & 333 & - & - \\
\hline Urea & 61 & - & - \\
\hline Soya-bean meal ${ }^{\dagger}$ & - & 873 & 333 \\
\hline Rapeseed meal $^{\dagger}$ & - & 127 & 333 \\
\hline White-fish meal & - & - & 333 \\
\hline
\end{tabular}

${ }^{\dagger}$ Solvent extracted. were formulated to achieve dietary CP contents of 130, 165 and $170 \mathrm{~g} / \mathrm{kg} \mathrm{DM}$, respectively. The three protein supplements had differing RDP:UDP ratios, namely, 3.0, 1.4 and 0.9:1 and were termed CON (control), LUDP (low UDP) and HUDP (high UDP), respectively. Thorough mixing of the forage and concentrate components was achieved using a small, self-propelled mixer wagon (Data Ranger, American Calan Inc., USA). The different protein fractions of the resultant diets, namely QDP, SDP and UDP were calculated using the $a, b$ and $c$ values determined by applying the Fitcurve Excel software package (XBC Laboratories, Rowett Institute, Aberdeen) to in sacco degradability (Ørskov and Mehrez, 1977) and acid-detergent insoluble nitrogen (ADIN) results of the three experimental concentrates and maize silage used in this study. In sacco degradability results were obtained from serial incubations of each sample using an established rumen-fistulated dairy cow receiving a predominantly maize-silage-based diet.

\section{Animal management}

Animals were home produced and reared and housed throughout the summer in groups of approximately 12 animals, comprising one breed of mixed gender, in strawbedded yards. The initial diet during this period comprised maize silage supplemented with $0.75 \mathrm{~kg}$ of ground wheat and $0.75 \mathrm{~kg}$ (fresh weight) per head of maize-gluten meal provided as one meal, top dressed on the silage. Animals were weighed on alternate weeks during the summer months and treated twice at 6-week intervals with a topical application of Spot $\mathrm{On}^{\mathrm{TM}}$ (1\% w/v Deltamethrin; Pitman-Moore Ltd, Crewe, Cheshire) for the control of lice and flies.

\section{Animals and experimental design}

This study was of a randomised complete block design and comprised of 24 Simmental $\times$ Holstein-Friesian (SHF) castrated males (steers), 24 SHF entire males (bulls), 24 Holstein-Friesian (HF) steers and $24 \mathrm{HF}$ bulls. Equal numbers of each breed and gender were randomly allocated to one of the three dietary treatments and to one of two housing/feeding regimes, either group pens or yards fitted with individual electronic gates.

Animals in the group pens were bedded on wheat straw and fed one of the three dietary treatments. Each pen contained four animals, two of each breed but of the same gender. This resulted in two replicates of each dietary-gender treatment. The six yards each contained eight electronic gates, and eight cubicles fitted with rubber mats that were scraped daily. No other bedding substrate was provided in these pens. Each pen contained eight animals, four of each breed but all of the same gender.

At the beginning of the experiment animals were blocked according to live weight (LW), with each block of animals housed in a separate pen, thus ensuring that all cattle in the same pen were of a similar LW at the beginning of the study. Mean start LW was $473 \pm 9.3 \mathrm{~kg}$ for bulls and $458 \pm 7.8 \mathrm{~kg}$ for steers. Animals were not 
moved between pens for the duration of the study so that established peer groups were maintained throughout.

\section{Animal performance measurements}

Individual DMI was only recorded on those animals fed through electronic gates, by weighing feed offered and refused on a daily basis. The total mixed ration was offered once daily ad libitum, maintaining refusals at approximately $150 \mathrm{~g} / \mathrm{kg}$ of daily intake. The same total mixed rations were offered ad libitum to animals fed in group pens. LW was recorded on two consecutive days at the beginning of the experiment and on two consecutive occasions when animals reached their designated target slaughter weight. Throughout the trial, LW of all cattle was recorded at 2-week intervals.

\section{Slaughter}

All cattle were slaughtered at the Division of Food Animal Science, University of Bristol, having reached a minimum LW of $560 \mathrm{~kg}$ for steers and $610 \mathrm{~kg}$ for bulls. Cattle were weighed on two consecutive days, on the day of and day prior to transportation to the abattoir, to give a mean final LW. Cattle were removed from their respective pens at the time of transportation in order to reduce unnecessary stress from mixing bulls from different peer groups.

Animals were transported to Bristol, on the day of slaughter, in groups of between two and five cattle. Cattle were slaughtered by captive bolt followed by exsanguination. Carcasses were dressed by removal of the head, tail, feet and the abdominal and thoracic viscera. Kidney knob and channel fat were left inside the carcass and no other fat depots were trimmed before each carcass side was weighed and graded. All carcasses were visually graded for conformation and external fat cover using two classification scales; the European Carcass Classification Scheme (Kempster et al., 1982) and 15-point scale (De Boer et al., 1974). Killing-out (KO) percentage was calculated as the proportion of cold carcass weight to final LW.

\section{Feed analysis}

Oven DM content was determined by drying samples in a forced-draught oven at $100^{\circ} \mathrm{C}$ for $24 \mathrm{~h}$ (concentrates and silage). Organic matter (OM) content was obtained by difference after ashing the dried sample in a muffle furnace at $550^{\circ} \mathrm{C}$ for $16 \mathrm{~h}$. Neutral-detergent fibre (NDF) and aciddetergent fibre (ADF) were determined by ANKOM-Fibre analyser 200 (ANKOM-Technology, Fairport, NY, USA) using the procedures described by Ministry of Agriculture, Fisheries and Food (MAFF, 1993 and 1986), respectively. Sodium dodecyl sulphate and alpha amylase solution were used in the NDF procedure. The values for NDF and ADF are corrected for residual ash (MAFF, 1993). Starch was determined by polarimetry (MAFF, 1982) with random samples analysed using the enzymatic technique (MacRae and Armstrong, 1968) to verify calibration of the polarimeter. Ammonium-nitrogen and oil content were determined as described in MAFF (1986 and 1993).
Metabolisable energy (ME) contents were predicted from neutral cellulase plus gammanase (NCGD) and oil content as described in MAFF (1993).

\section{Statistical analysis}

Statistically significant differences between individual treatments were determined by analysis of variance (ANOVA) using the GLM procedure (Minitab software version 13). The data set contained 48 observations for DMI and 96 observations for LWG. The model for DMI consisted of diets ( 2 d.f.), breed (1 d.f.) and gender ( 1 d.f.) as sources of variation. The model for LWG consisted of diet ( $2 \mathrm{d.f.}$ ), feeding system (1 d.f.), breed (1 d.f.), and gender (1 d.f.) as sources of variation. Start weight was used as a covariate term in the statistical analysis of all measured variables. Interactions between main effects were investigated at the first, second and third order. Results are presented as least-square means (LSM) with the standard error of the difference (s.e.d.).

\section{Results}

Dry-matter and nutrient intake

As indicated, individual animal measurements of feed consumption were only possible for those cattle retained in cubicle housing and fed through individual electronic gates. Overall, DMI was marginally $(P=0.102)$ higher for diet LUDP when compared with diets CON and HUDP (Table 2), whilst SHF consumed significantly less DM, both total and per kg metabolic weight $\left(\mathrm{M}^{0.75}\right)(P<0.05)$ than HF. Steers were also noted to consume significantly less total DM $(P<0.05)$ than bulls, but when intakes were expressed in relation to $\mathrm{M}^{0.75}$ the difference between bulls and steers was not evident. There were no first or second order interactions between breed, gender and diet. More $\mathrm{CP}$, starch, NDF and ME were consumed by HF when compared with SHF and by bulls compared with steers. However, as expected, when intakes of $C P$, starch, NDF and ME were expressed in terms of metabolic live weight, differences between bulls and steers were not different $(P>0.05)$. There were no statistical differences in ME intake between any of the diets with a mean estimated intake of $118 \mathrm{MJ} /$ day. Animals that received diets HUDP and LUDP consumed more CP than those fed diet CON. In contrast, intakes of starch were higher in diet CON than for HUDP and LUDP, due to the inclusion of wheat and peas in the CON concentrate blend. Intake of NDF was significantly greater for diet LUDP than diet HUDP, and greater for diet HUDP than diet CON. There were no first or second order interactions between any of the variables for nutrient intake.

\section{Animal performance}

There were differences in the mean overall start LW between breeds as the HF were slightly heavier than the SHF, and steers slightly lighter than bulls, but none of these differences was greater than $20 \mathrm{~kg}$ (Table 3). There 
Juniper, Bryant, Beever and Fisher

Table 2 Dry-matter intake (DMI) and nutrient intake of finishing beef animals of different gender and breed fed behind either electronic gates or in group pens whilst receiving maize-silage-based diets of contrasting crude protein concentrations (units per day unless otherwise stated)

\begin{tabular}{|c|c|c|c|c|c|c|c|c|c|c|c|c|c|}
\hline & \multicolumn{2}{|c|}{ Breed $^{\dagger}$} & \multirow[b]{2}{*}{ s.e.d. } & \multirow[b]{2}{*}{$P$ value } & \multicolumn{2}{|c|}{ Gender } & \multirow[b]{2}{*}{ s.e.d. } & \multirow[b]{2}{*}{$P$ value } & \multicolumn{3}{|c|}{ Diet } & \multirow[b]{2}{*}{ s.e.d. } & \multirow[b]{2}{*}{$P$ value } \\
\hline & SHF & $\mathrm{HF}$ & & & Bull & Steer & & & CON & LUDP & HUDP & & \\
\hline DMI (kg) & 10.54 & 11.41 & 0.273 & 0.003 & 11.30 & 10.64 & 0.273 & 0.021 & 10.75 & 11.39 & 10.78 & 0.323 & 0.102 \\
\hline DMI per $\mathrm{M}^{0.75}(\mathrm{~kg})$ & 0.095 & 0.102 & 0.003 & 0.016 & 0.100 & 0.097 & 0.003 & 0.297 & 0.097 & $7 \quad 0.102$ & 0.097 & 0.003 & 0.128 \\
\hline Metabolisable energy (MJ) & 113.5 & 122.6 & 2.81 & 0.003 & 121.6 & 114.5 & 2.83 & 0.015 & 116.1 & 122.0 & 116.0 & 3.38 & 0.141 \\
\hline Crude protein (g) & 1739 & 1860 & 48.4 & 0.018 & 1847 & 1753 & 47.8 & 0.0581 & $1532^{\mathrm{a}}$ & $1983^{b} \quad 1$ & $1918^{b}$ & 56.7 & $<0.001$ \\
\hline Starch (g) & 3014 & 3258 & 73.8 & 0.002 & 3224 & 3048 & 73.4 & 0.0213 & $3716^{\mathrm{a}}$ & $2918^{b} \quad 2$ & $2775^{b}$ & 91.4 & $<0.001$ \\
\hline Neutral-detergent fibre (g) & 4020 & 4343 & 102.4 & 0.003 & 4314 & 4048 & 101.8 & 0.0123 & $3680^{\mathrm{a}}$ & $4702^{b} \quad 4$ & $4168^{c}$ & 126.8 & $<0.001$ \\
\hline
\end{tabular}

a,b,c Means with different superscripts differ significantly $(P<0.05)$.

${ }^{\dagger} \mathrm{SHF}=$ Simmental cross Holstein-Friesian; $\mathrm{HF}=$ Holstein-Friesian.

were no statistical differences between dietary treatments in mean start LW; either in the group or individually fed animals, with mean values $462 \pm 8.8$ and $465 \pm 8.4 \mathrm{~kg}$ respectively.

Bulls had predetermined heavier slaughter weights than steers, the target finishing weights being $620 \mathrm{~kg}$ and $580 \mathrm{~kg}$ respectively. There were no differences in finishing weight between breeds in either the group or individually fed systems. Animals receiving diet CON finished lighter than those receiving diet LUDP $(P<0.05$ in the pooled results only). Animals fed through electronic gates had significantly greater $(P<0.005)$ rates of LWG than animals fed in the group system with average daily gains for electronic gates and group pens of 1.58 and $1.40 \mathrm{~kg} / \mathrm{day}$, respectively. Consequently, animals fed through electronic gates took significantly less time to reach their target slaughter weight. As expected, bulls had significantly $(P<0.001)$ greater rates of LWG than steers, although there were no statistical differences in time taken to reach the target slaughter weight, a result of the different predetermined slaughter target weights for each gender. However, there was a significant feeding system by gender interaction $(P<0.001)$ where bulls fed through electronic gates had considerably greater rates of gain and reduced days to slaughter than bulls fed in group pens (Table 4). In contrast, the gains and time to slaughter in steers were similar between the two systems. Overall, SHF had greater LWGs than HF, a result that was more pronounced in group-fed cattle. This suggested a breed by system interaction, but this failed to reach statistical significance. Animals that received diet CON grew slower than those fed diets LUDP and HUDP, irrespective of feeding system. However, an interaction between breed and diet was determined whereby SHF responded better to diets LUDP and HUDP than the HF, resulting in a significantly $(P<0.05)$ reduced time to reach target slaughter weight in SHF on

Table 3 Start live weights (LW), finish LW and physical performance of finishing beef cattle of different gender and breed fed behind either electronic gates or in group pens whilst receiving maize-silage-based diets of contrasting crude protein concentrations

\begin{tabular}{|c|c|c|c|c|c|c|c|c|c|c|c|c|c|}
\hline & \multicolumn{2}{|c|}{ Breed $^{\dagger}$} & \multirow[b]{2}{*}{ s.e.d. } & \multirow[b]{2}{*}{$P$ value } & \multicolumn{2}{|c|}{ Gender } & \multirow[b]{2}{*}{ s.e.d. } & \multirow[b]{2}{*}{$P$ value } & \multicolumn{3}{|c|}{ Diet } & \multirow[b]{2}{*}{ s.e.d. } & \multirow[b]{2}{*}{$P$ value } \\
\hline & SHF & HF & & & Bull & Steer & & & CON & LUDP & HUDP & & \\
\hline \multicolumn{14}{|l|}{ Electronic gates } \\
\hline Start LW (kg) & 460.3 & 478.1 & 9.30 & 0.065 & 477.0 & 461.4 & 9.27 & 0.102 & 470.8 & 468.0 & 468.8 & 11.55 & 0.970 \\
\hline Finish LW (kg) & 601.3 & 603.3 & 3.14 & 0.529 & 618.4 & 586.1 & 3.13 & $<0.001$ & 577.7 & 607.1 & 600.8 & 3.90 & 0.107 \\
\hline $\mathrm{DLWG}^{\dagger}$ (kg/day) & 1.63 & 1.54 & 0.019 & 0.344 & 1.82 & 1.34 & 0.091 & $<0.001$ & $1.43^{a}$ & $1.69^{b}$ & $1.64^{\mathrm{ab}}$ & 0.114 & 0.066 \\
\hline Days to slaughter & 83 & 96 & 5 & 0.025 & 89 & 90 & 5 & 0.836 & 97 & 85 & 87 & 6 & 0.149 \\
\hline $\mathrm{FCR}^{\dagger}(\mathrm{kg} \mathrm{DMI} / \mathrm{LWG})$ & 6.76 & 7.79 & 0.328 & 0.003 & 6.45 & 8.11 & 0.327 & $<0.001$ & 7.80 & 6.99 & 7.05 & 0.464 & 0.103 \\
\hline \multicolumn{14}{|l|}{ Group pens } \\
\hline Start LW (kg) & 455.3 & 469.9 & 10.21 & 0.159 & 467.3 & 457.9 & 10.21 & 0.364 & 456.1 & 468.6 & 463.1 & 12.50 & 0.612 \\
\hline Finish LW (kg) & 602.4 & 604.6 & 4.34 & 0.613 & 617.4 & 589.6 & 4.34 & $<0.001$ & 598.9 & 609.4 & 602.2 & 5.31 & 0.141 \\
\hline DLWG (kg/day) & 1.50 & 1.29 & 0.068 & 0.004 & 1.43 & 1.36 & 0.068 & 0.308 & $1.25^{\mathrm{a}}$ & $1.43^{\mathrm{ab}}$ & $1.52^{\mathrm{b}}$ & 0.083 & 0.009 \\
\hline Days to slaughter & 96 & 111 & 4 & $<0.001$ & 110 & 97 & 4 & $<0.001$ & $112^{\mathrm{a}}$ & $104^{a b}$ & $95^{b}$ & 5 & 0.002 \\
\hline \multicolumn{14}{|l|}{ Overall } \\
\hline Start weight (kg) & 457.9 & 473.6 & 6.80 & 0.023 & 471.8 & 459.7 & 6.79 & 0.077 & 463.0 & 468.4 & 465.9 & 8.37 & 0.815 \\
\hline Finish weight $(\mathrm{kg})$ & 601.8 & 603.8 & 2.65 & 0.453 & 617.8 & 587.9 & 2.65 & $<0.001$ & $598.8^{\mathrm{a}}$ & $608.2^{\mathrm{b}}$ & $601.6^{\mathrm{ab}}$ & 3.26 & 0.015 \\
\hline DLWG (kg/day) & 1.57 & 1.42 & 0.060 & 0.009 & 1.63 & 1.36 & 0.059 & $<0.001$ & $1.36^{\mathrm{a}}$ & $1.56^{\mathrm{b}}$ & $1.57^{\mathrm{b}}$ & 0.071 & 0.005 \\
\hline Days to slaughter & 90 & 104 & 4 & $<0.001$ & 100 & 95 & 4 & 0.147 & $104^{a}$ & $95^{b}$ & $92^{\mathrm{b}}$ & 4 & 0.025 \\
\hline
\end{tabular}

${ }^{\mathrm{a}, \mathrm{b}}$ Means with different superscripts differ significantly $(P<0.05)$.

${ }^{\dagger}$ Abbreviations are: DLWG = daily live-weight gain; FCR = feed conversion ratio; SHF = Simmental cross Holstein-Friesian; HF = Holstein-Friesian. 
Table 4 First order interaction in daily live-weight gain (DLWG) and days to slaughter between feeding system and gender of finishing beef animals receiving maize-silage-based diets of contrasting crude protein concentrations

\begin{tabular}{lcccccccc}
\hline \hline & \multicolumn{2}{c}{ Group } & & \multicolumn{2}{c}{ Electronic } & & \\
\cline { 2 - 3 } & Bull & Steer & & Bull & Steer & s.e.d. & $P$ value \\
\hline DLWG (kg/day) & $1.43^{\mathrm{a}}$ & $1.38^{\mathrm{a}}$ & & $1.82^{\mathrm{b}}$ & $1.35^{\mathrm{a}}$ & 0.085 & 0.001 \\
Days to slaughter & $108^{\mathrm{a}}$ & $95^{\mathrm{b}}$ & & $91^{\mathrm{b}}$ & $95^{\mathrm{b}}$ & 5 & 0.009 \\
\hline \hline
\end{tabular}

${ }^{a, b}$ Means with different superscripts differ significantly $(P<0.05)$.

protein supplemented rations (Table 3 ). Feed conversion ratios were significantly $(P<0.05)$ improved in SHF compared with HF and in bulls compared with steers, whilst animals fed diet CON had poorer feed conversion ratios than those receiving diets LUDP and HUDP, although the difference failed to reach statistical significance.

\section{Carcass characteristics}

SHF had better KO percentages than HF (55.9 v. 54.9\%, $P<0.01$ ), which was reflected in the marginally higher carcass weights of SHF, given that the two breeds were slaughtered at relatively similar LWs. Steers had significantly $(P<0.001)$ higher KO percentages than bulls (56.1 v. 54.7, $P<0.001$ ), despite bulls having heavier carcass weights compared with steers, due to the higher target slaughter weight of bulls. Diet did not appear to influence either KO percentage or carcass weight (mean $\mathrm{KO} \%=55.4$ ). Neither diet, gender nor feeding system significantly influenced conformation scores on either the Meat and Livestock Commission (MLC) or 15-point scoring systems (Table 5), although the difference between MLC conformation scores for diet CON and diets LUDP and HUDP did approach statistical significance $(P=0.055)$. With respect to breed, SHF had significantly higher $(P<0.05)$ conformation scores than $\mathrm{HF}$ on both the MLC and 15-point systems. Fat scores on both systems were not significantly influenced by breed, diet or housing system. However, steers had significantly greater $(P<0.005)$ fat scores than bulls. There was a significant $(P<0.05)$ first order interaction between gender and dietary treatment in that bulls and steers had similar MLC fat scores in treatment LUDP, but bulls, when compared with steers, had considerably lower scores in diets CON and HUDP (Table 6). This trend was also apparent using the 15-point fat score system but at a lower overall level of significance. Breed did not appear to influence fat scores on either system. However, there was a feeding system by breed interaction whereby SHF fed in straw-bedded group pens had significantly lower $(P<0.05)$ MLC fat scores than SHF fed through electronic gates (Table 7). In contrast, HF had marginally higher MLC fat scores when fed in straw-bedded group pens when compared with electronic gates. This trend was also apparent when the 15-point fat scoring system was applied, although some discrepancy occurs between the two scales so far as statistical interpretation is concerned.

\section{Discussion}

Feed intakes have been shown to be depressed when diets containing low levels of dietary CP have been offered to growing cattle. Bastiman (1975) reported an overall, but not significant, reduction in feed intake when dietary $C P$ content for intensively fed beef cattle was reduced from 159 to $132 \mathrm{~g} / \mathrm{kg}$, while Kay and Macdearmid (1973) found that intakes by fattening cattle were reduced when dietary $\mathrm{CP}$ concentration fell below $115 \mathrm{~g} / \mathrm{kg}$. The lowest overall protein concentration used in this study was $142 \mathrm{~g} / \mathrm{kg} \mathrm{DM}$, and intake was not systematically influenced by increasing levels of dietary $C P$, with mean DM intakes of 10.8, 11.4 and $10.8 \mathrm{~kg} /$ day for diets CON, LUDP and HUDP, respectively. In addition, there have been conflicting reports on the effect of protein type (high $v$. low degradable) on DMI. Tomlinson et al. (1997) reported that as the proportion of UDP increased in relation to total dietary CP content, it was accompanied by a commensurate decrease in DMI, whereas Newbold et al. (1990) reported that intake in neither bulls nor steers was affected by dietary protein

Table 5 Killing-out percentage, carcass weight, fat scores, and conformation scores of finished beef cattle of different gender and breed fed behind either electronic gates or in group pens whilst receiving maize-silage-based diets of contrasting crude protein concentrations

\begin{tabular}{|c|c|c|c|c|c|c|c|c|c|c|c|c|c|}
\hline & \multicolumn{2}{|c|}{ Breed $^{\dagger}$} & \multirow[b]{2}{*}{ s.e.d. } & \multirow[b]{2}{*}{$P$ value } & \multicolumn{2}{|c|}{ Gender } & \multirow[b]{2}{*}{ s.e.d. } & \multirow[b]{2}{*}{$P$ value } & \multicolumn{3}{|c|}{ Diet } & \multirow[b]{2}{*}{ s.e.d. } & \multirow[b]{2}{*}{$P$ value } \\
\hline & SHF & $\mathrm{HF}$ & & & Bull & Steer & & & CON & LUDP & HUDP & & \\
\hline Killing-out percentage & 55.9 & 54.9 & 0.36 & 0.009 & 54.7 & 56.1 & 0.36 & $<0.001$ & 55.3 & 55.0 & 55.9 & 0.44 & 0.123 \\
\hline $\begin{array}{l}\text { Carcass weight }(\mathrm{kg}) \\
\mathrm{MLC}^{\ddagger}\end{array}$ & 336.3 & 331.6 & 2.29 & 0.043 & 338.1 & 329.9 & 2.29 & $<0.001$ & 331.0 & 334.6 & 336.3 & 2.83 & 0.173 \\
\hline Fat score & 65.56 & 66.11 & 4.700 & 0.908 & 53.58 & 78.09 & 4.700 & $<0.001$ & 64.79 & 65.73 & 66.99 & 5.958 & 0.931 \\
\hline Conformation score & 88.85 & 52.85 & 4.029 & $<0.001$ & 68.68 & 73.02 & 4.029 & 0.286 & 63.28 & 74.43 & 74.84 & 5.127 & 0.055 \\
\hline \multicolumn{14}{|l|}{ 15-point } \\
\hline Fat score & 6.97 & 6.40 & 0.467 & 0.230 & 5.64 & 7.73 & 0.467 & $<0.001$ & 6.59 & 6.27 & 7.19 & 0.526 & 0.216 \\
\hline Conformation score & 8.55 & 5.71 & 0.316 & $<0.001$ & 7.24 & 7.02 & 0.316 & 0.493 & 6.87 & 7.22 & 7.31 & 0.401 & 0.527 \\
\hline
\end{tabular}

${ }^{\dagger} \mathrm{SHF}=$ Simmental cross Holstein-Friesian; $\mathrm{HF}=$ Holstein-Friesian.

${ }^{\ddagger}$ Fat score basis: $20=1,45=2,65=3,90=4 \mathrm{~L}$. Conformation score basis: $20=\mathrm{P}, 30=-0,55=0+, 85=\mathrm{R}, 115=-\mathrm{U}$. 
Juniper, Bryant, Beever and Fisher

Table 6 First order interaction in fat scores between dietary treatment and gender of finishing beef animals receiving maize-silage-based diets of contrasting crude protein concentrations

\begin{tabular}{|c|c|c|c|c|c|c|c|c|}
\hline & \multicolumn{3}{|c|}{ Bulls } & \multicolumn{3}{|c|}{ Steers } & \multirow[b]{2}{*}{ s.e.d. } & \multirow[b]{2}{*}{$P$ value } \\
\hline & CON & LUDP & HUDP & CON & LUDP & HUDP & & \\
\hline MLC fat score & $51.04^{\mathrm{ac}}$ & $62.29^{\mathrm{ac}}$ & $47.42^{c}$ & $78.54^{\mathrm{b}}$ & $69.17^{\mathrm{ab}}$ & $86.56^{\mathrm{b}}$ & 9.29 & 0.013 \\
\hline 15-point fat score ${ }^{\dagger}$ & $5.625^{a}$ & $5.846^{\mathrm{a}}$ & $5.442^{\mathrm{a}}$ & $7.562^{\mathrm{a}}$ & $6.688^{\mathrm{a}}$ & $8.938^{b}$ & 0.925 & 0.048 \\
\hline
\end{tabular}

a,b Means with different superscripts differ significantly $(P<0.05)$.

${ }^{\dagger}$ 15-point scale of De Boer et al. (1974).

degradability. Bethard et al. (1997) reported that DMI was not influenced by the UDP content of the diet but by energy intake. However, these workers found an interaction between dietary energy and UDP contents such that animals receiving high energy/low UDP diets had greater intakes than those animals receiving diets of low energy/ low UDP, low energy/high UDP or high energy/high UDP. It was postulated that low energy concentrations may have resulted in a lack of fermentable substrate with compromised microbial digestibility of DM resulting in reduced DMI, whereas at high energy concentrations, DMI and microbial growth were likely to be improved, possibly resulting in sufficient amino acid flow to the small intestine and masking any effect of increased UDP supply. The different proportions of the RDP fractions used in this study did not appear to influence intakes.

It is generally accepted that bulls have higher total feed DMI than steers and this effect was confirmed in the present study. However, Anderson et al. (1988) questioned whether the greater intake of bulls reflected increased appetite or was simply a function of higher body weights. They reported that Simmental bulls receiving identical diets to Simmental steers consumed greater quantities of feed, but when expressed in terms of $\mathrm{kg} \mathrm{M}^{0.75}$, intakes between the two genders ceased to be statistically significant. This effect was confirmed in the present study (bulls, 100;

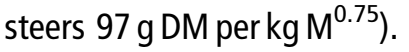

HF consumed significantly greater quantities of DM than SHF and this effect was still evident when intake was expressed in terms of metabolic live weight (HF, 102, SHF, $95 \mathrm{~g}^{\mathrm{kg} \mathrm{M}}{ }^{0.75}$ ). The HF breed, over the years, has been selected to maximise milk yield as there is a relatively strong genetic correlation between yield and the efficiency

Table 7 First order interaction in fat scores between feeding system and breed $^{+}$of finishing beef animals receiving maize-silage-based diets of contrasting crude protein concentrations

\begin{tabular}{lcccccc}
\hline \hline & \multicolumn{2}{c}{ Group } & & \multicolumn{2}{c}{ Electronic } & \\
\cline { 2 - 3 } & SHF & HF & SHF & HF & s.e.d. $P$ value \\
\hline MLC fat score & $56.11^{\mathrm{a}}$ & $71.04^{\mathrm{ab}}$ & $75.01^{\mathrm{b}}$ & $61.18^{\mathrm{ab}}$ & 6.80 & 0.003 \\
15 -point fat score & $6.361^{\mathrm{ab}}$ & $6.750^{\mathrm{ab}}$ & $7.572^{\mathrm{a}}$ & $6.050^{\mathrm{b}}$ & 0.643 & 0.045 \\
\hline \hline
\end{tabular}

${ }^{a, b}$ Means with different superscripts differ significantly $(P<0.05)$.

${ }^{\dagger} \mathrm{SHF}=$ Simmental cross Holstein-Friesian; $\mathrm{HF}=$ Holstein-Friesian.

¥15-point scale of De Boer et al. (1974). of production. As a consequence, in addition to selecting animals based on traits for increased milk yield, these animals are now selected for increased feed intake (Simm, 1998), which may have contributed to the greater intakes by HF bulls and steers when expressed in relation to metabolic body size.

Overall daily LWG improved significantly between diet CON and both protein supplemented diets, with no discernable effects due to the type of protein contained in the supplement. Improvements in LWG in response to increasing dietary CP concentration depend on genotype, gender and physiological age, all of which can influence the animals' potential for lean tissue deposition. As animals mature, their capacity for lean tissue deposition declines. Consequently, supplying MP supply above that needed for (i) maintenance and (ii) level of lean tissue growth occurring at this time is unlikely to result in any significant improvements in LWG (Bergen and Merkel, 1991). In this situation, nutrients supplied in excess of that required for maintenance and lean tissue deposition would be retained in the body as fat (Campbell, 1988). The lack of any improvement in LWG between diets LUDP and HUDP may have been as a consequence of MP supply being in excess of that required for maintenance and lean tissue deposition, given that the animals used in this study were nearing maturity, and as such would be expected to have lower protein accretion rates and consequently lower MP requirements for growth.

Bulls predictably grew faster than steers, with overall gains of 1.63 and $1.36 \mathrm{~kg} / \mathrm{day}$, respectively. However, differences between the two different housing systems (straw yards $v$. electronic gates) in the overall rates of LWG were amplified between the two genders leading to a significant interaction between gender and housing systems. Bulls fed in straw bedded group pens had LWGs of $1.43 \mathrm{~kg} / \mathrm{day}$ compared with those fed through electronic gates and bedded on rubber mats where gains averaged $1.82 \mathrm{~kg} /$ day.

Theoretical estimates, based on ARC (1980) equations, for protein and energy required for maintenance and observed rates of growth for the bulls and steers fed in each system are shown in Table 8. The significant reduction in LWG seen in bulls housed in straw yards was accompanied by reductions in ME (18 MJ/day) and MP requirements ( $72 \mathrm{~g} /$ day) when compared with bulls fed through individual electronic gates. If it is assumed that animals of like gender being fed identical diets, whether 
Table 8 Estimates of protein and energy requirements to achieve observed rates of gain in bulls and steers receiving maize-silagebased rations fed behind either electronic gates or in straw bedded group pens

\begin{tabular}{|c|c|c|c|c|}
\hline & \multicolumn{2}{|c|}{ Group pens } & \multicolumn{2}{|c|}{$\begin{array}{c}\text { Electronic } \\
\text { gates }\end{array}$} \\
\hline & Bulls & Steers & Bulls & Steers \\
\hline DLWG (kg/day) & 1.43 & 1.38 & 1.82 & 1.35 \\
\hline Protein maintenance $\left(\mathrm{MP}_{\mathrm{m}}, \mathrm{g} / \text { day }\right)^{1}$ & 260 & 252 & 260 & 252 \\
\hline Protein for growth $\left(\mathrm{MP}_{\mathrm{f}}, \mathrm{g} / \text { day }\right)^{2}$ & 343 & 304 & 415 & 299 \\
\hline Total protein requirement (g/day) & 603 & 556 & 675 & 551 \\
\hline ME maintenance $\left(\mathrm{M}_{\mathrm{m}}, \mathrm{MJ} / \mathrm{day}\right)^{3}$ & 60.6 & 51.1 & 60.6 & 51.1 \\
\hline ME growth $\left(M_{f}, M J / \text { day }\right)^{4}$ & 49.2 & 55.2 & 67.6 & 53.9 \\
\hline Total ME requirement (MJ/day) & 109.8 & 106.3 & 128.2 & 105.0 \\
\hline \multicolumn{5}{|c|}{$\begin{array}{l}{ }^{1} \mathrm{MP}_{\mathrm{m}}=2.30 \mathrm{M}^{0.75} \\
{ }^{2} \mathrm{MP}_{\mathrm{f}}=\mathrm{C} 6\left\{168.07-0.16869 \mathrm{~W}+0.0001633 \mathrm{~W}^{2}\right\} \times\{1.12-0.1223 \\
\Delta \mathrm{W}\} \times 1.695 \Delta \mathrm{W} \text { where } \mathrm{C} 6=\text { correction factor for maturity group and gender. } \\
{ }^{3} \mathrm{ME} \mathrm{E}_{\mathrm{m}}=\mathrm{k}_{\mathrm{m}}\left(\left(\mathrm{C} 1\left\{0.53[\mathrm{~W} / 1.08]^{0.67}\right\}\right)+0.0071 \mathrm{~W}\right) \text { where } \mathrm{k}_{\mathrm{m}}=\text { efficiency of util- } \\
\text { isation of } \mathrm{ME} \text { for maintenance and } \mathrm{C} 1=\text { correction factor for maturity group } \\
\text { and gender. } \\
{ }^{4} \mathrm{ME}_{\mathrm{f}} \quad(\mathrm{MJ} / \mathrm{kg})=\mathrm{k}_{\mathrm{f}}\left(\left(\mathrm{C} 2\left[4.1+0.0332 \mathrm{~W}-0.000009 \mathrm{~W}^{2}\right] / 0.1475 \Delta \mathrm{W} \text { where }\right.\right. \\
\mathrm{k}_{\mathrm{f}}=\text { efficiency of utilisation of } \mathrm{ME} \text { for live-weight gain and } \mathrm{C} 2=\text { correction } \\
\text { factor for maturity group and gender. }\end{array}$} \\
\hline
\end{tabular}

housed in group pens or behind electronic gates, had similar potential for DMI and growth, then it must be concluded that the straw-bedded bulls were experiencing some nutritional deprivation. This could have been due to either (i) limitation of DMI as a result of bullying at the feed barrier or (ii) nutritional dilution of the diet due to significant ingestion of straw bedding. In turn, both of these would have affected feed conversion ratio.

If the limitation in intake was the result of bullying it could have resulted in increased standard errors in the growth rates of group-fed compared with individually fed bulls. This did not however occur, suggesting that bullying was unlikely to have been the cause of the observed reduction in animal performance. The effects of straw intake resulting in nutritional dilution may provide a better explanation, as regression analysis of LWG against ME intake indicated that bulls, when compared with steers, show continued LWG responses to higher ME intakes. Furthermore, extrapolation of the resultant equations obtained by regressing LWG against MP:ME ratios indicated that steers achieved their maximal response at a ratio of $9 \mathrm{~g}$ MP per MJ compared with $11 \mathrm{~g}$ MP per MJ for bulls. The intake of significant amounts of straw could have resulted in an overall reduction in ME intake and a perturbation in the MP:ME ratio, which may have led to the consequential reduction in the growth rates of bulls housed on the straw system. No estimate of straw intake was possible and thus it is not possible to quantify the changes that may have occurred.

In addition to the interaction between gender and feeding system there was a further, but not significant interaction between breed and dietary treatment. SHF and HF showed similar rates of LWG when receiving the low protein diet (CON). However, LWGs in SHF increased by $0.49 \mathrm{~kg} /$ day when they received diet LUDP compared with only $0.02 \mathrm{~kg} /$ day improvement in $\mathrm{HF}$ receiving the same diet. Both SHF and HF are classed as late-maturing breeds and as such share similar theoretical MP and ME requirements for maintenance and LWG (Agricultural and Food Research Council (AFRC), 1995). Table 9 shows the calculated estimates of gain that could be anticipated from calculated nutrient intakes. These data are compared with the actual rates of LWG and the protein and ME requirements needed to meet maintenance and observed gains.

When observed gains were compared with predicted gains (AFRC, 1995) it can be seen that both the SHF and the $\mathrm{HF}$ responded in similar ways at the lower protein level such that estimates of potential LWGs were within $0.14 \mathrm{~kg} /$ day of observed values. As dietary protein concentration increased HF fed LUDP became less efficient at utilising available $M E$, with actual gains at least $0.23 \mathrm{~kg} /$ day lower than estimated. Conversely, SHF showed the opposite trend and achieved gains on LUDP and HUDP that exceeded estimates by $0.23 \mathrm{~kg} /$ day.

The carcasses of HF had lower KO percentages than SHF, which is consistent with the findings of Kempster et al. (1988). Furthermore, Kempster et al. (1988) reported

Table 9 Estimates of metabolisable protein (MP) and metabolisable energy (ME) requirements of Simmental crosses (SHF) and Holstein-Friesians (HF) and the supplies provided by maize-silage-based diets of contrasting crude protein concentrations

\begin{tabular}{|c|c|c|c|c|c|c|}
\hline & \multicolumn{3}{|c|}{ SHF } & \multicolumn{3}{|c|}{ HF } \\
\hline & CON & LUDP & HUDP & CON & LUDP & HUDP \\
\hline MP intake (g/day) & 785 & 1019 & 1150 & 859 & 1110 & 1189 \\
\hline ME intake (MJ/day) & 111.1 & 116.9 & 113.8 & 121.2 & 127.0 & 117.5 \\
\hline Estimated rate of growth $(\mathrm{kg} / \mathrm{day})^{\dagger}$ & 1.465 & 1.582 & 1.520 & 1.666 & 1.775 & 1.595 \\
\hline Recorded DLWG $(\mathrm{kg} / \text { day })^{\ddagger}$ & 1.36 & 1.85 & 1.73 & 1.53 & 1.55 & 1.54 \\
\hline MP requirement $(\mathrm{g} / \text { day })^{\S}$ & 571 & 657 & 637 & 602 & 606 & 604 \\
\hline ME requirement (MJ/day) $)^{\|}$ & 106.1 & 131.0 & 124.3 & 114.2 & 115.2 & 114.6 \\
\hline
\end{tabular}

\footnotetext{
${ }^{\dagger}$ Based on ME intake using the equation: gain $\left(\mathrm{kg} /\right.$ day) $=-0.0001 x^{2}+0.0424 x-2.0467$ where $x=\mathrm{ME}$ intake (MJ/day). Equation assumes a mean animal weight of $535.5 \mathrm{~kg}$.

${ }^{\ddagger}$ Rates of gain recorded through electronic gates. DLWG = daily live-weight gain.

${ }^{\S} \mathrm{MP}_{\text {req }}=\mathrm{MP}_{\mathrm{m}}+\mathrm{MP}_{\mathrm{f}}$. Assumes equal proportions of bulls and steers and mean weight of $535.5 \mathrm{~kg}$.

$" M E_{\text {req }}=M E_{m}+M E_{f}$. Assumes equal proportions of bulls and steers and mean weight of $535.5 \mathrm{~kg}$.
} 
Juniper, Bryant, Beever and Fisher

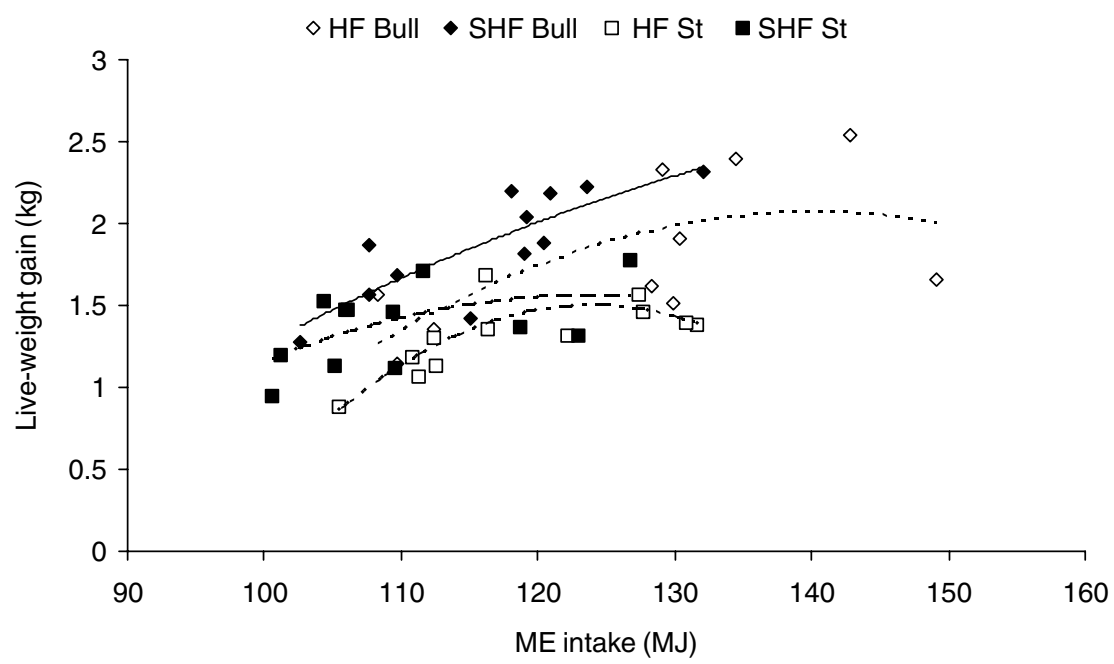

Figure 1 Relationship between daily metabolisable energy (ME) intake and daily live-weight gain of Holstein-Friesian (HF) and Simmental cross (SHF) bulls and steers.

lower lean tissue contents in the HF when compared with SHF, a finding attributed to their lower genetic potential for lean tissue deposition. However, carcass fat scores on both the 15-point and MLC scales in this study showed SHF and HF to have similar scores. Despite this lack of difference, it is feasible that HF may have partitioned greater quantities of ME to internal fat deposition, rather than lean tissue deposition, resulting in reduced efficiencies of LWG when compared with SHFs. In relation to MP, estimated supplies were well in excess of estimates of requirements to achieve the observed rates of LWG (ARC, 1980) in both SHF and HF. Furthermore, SHF receiving diets LUDP and HUDP exhibited rates of gain in excess of those estimated from the availability of ME. This would indicate that diets, rather than being protein limiting, may have been deficient in ME supply thus limiting the SHF maximal potential for growth. The relationship between ME intake and LWG for each breed by gender group is shown in Figure 1.

The regressions for HF and SHF steers both plateaux around $125 \mathrm{MJ}$ ME intake/day, suggesting maximal growth rates for this class and size of animal receiving the diets detailed in this study of approximately $1.7 \mathrm{~kg} /$ day (AFRC, 1995). The regression curve for HF bulls reaches a plateau at approximately $140 \mathrm{MJ} /$ day, equating to an approximate growth rate for this class and size of animal of $2.05 \mathrm{~kg} /$ day (AFRC, 1995). However, the regression curve for SHF bulls did not achieve a plateau, implying that the ME supplied to the animals during this study may not have been sufficient to meet the maximum growth potential of this class and size of animal.

The results of this experiment show that a modest increase in dietary CP concentration in maize-silage-based diets can result in improved rates of LWG in finishing Simmentals. However, similar increases in CP concentration failed to elicit the same responses in $\mathrm{HF}$, with animals displaying similar rates of gain irrespective of treatment. This would suggest that the late maturing classification for both HF and SHF should be revised in order to account for the two quite distinct growth patterns displayed by these cattle. The performance of animals in a system devoid of an edible bedding substrate was significantly improved, on average by $0.2 \mathrm{~kg} /$ day and in the case of bulls by $0.4 \mathrm{~kg} / \mathrm{day}$, thus significantly reducing the time taken for an animal to reach slaughter weight.

\section{Acknowledgements}

This study was part of a project funded by DEFRA, Meat and Livestock Commission, ABNA Agriculture, Tesco plc and the Maize Growers' Association. The authors would also like to thank Mr D. Cox, Mr J. Jenkins and Miss S.L. Gore for technical support during this study.

\section{References}

Agricultural and Food Research Council 1995. Energy and Protein Requirements of Ruminants. An advisory manual prepared by the AFRC Technical Committee on Responses to Nutrients. CAB INTERNATIONAL, Wallingford, UK.

Agricultural Research Council 1980. The nutrient requirements of ruminant livestock. Technical review by an Agricultural Research Council Working Party. Commonwealth Agricultural Bureaux, Farnham Royal, UK.

Anderson PT, Hawkins DR, Bergen WG and Merkel RA 1988. A note on the dry matter intake and composition of gain of Simmental bulls and steers fed to the same weight or age. Animal Production 47, 493-496.

Bastiman B 1975. The effect of different levels of protein in diets for intensive beef. Experimental Husbandry 29, 54-60.

Bergen BG and Merkel RA 1991. Protein accretion. In Growth regulation in farm animals (ed. AM Pearson and TR Dutson), pp. 169-202. Elsevier Applied Science, Amsterdam.

Bethard GL, James RE and McGilliard ML 1997. Effect of rumen undegradable protein and energy on growth and feed efficiency of growing Holstein heifers. Journal of Dairy Science 80, 2149-2155.

Campbell RG 1988. Nutritional constraints to lean tissue accretion in farm animals. Nutritional Research Reviews 1, 233-253. 
Cottrill BR, Beever DE, Austin AR and Osbourne DF 1982. The effect of protein and non-protein nitrogen supplements to maize silage on total amino acid supply in young cattle. British Journal of Nutrition 48, 527-541.

Cottrill BR and Osbourne DF 1977. The effect of source of nitrogen and energy supplementation on the utilisation of maize silage by young calves. Animal Production. 24, 127A.

De Boer H, Dumont BL, Pomeroy RW and Weniger JH 1974. Manual on EAAP methods for the assessment of carcass characteristics in cattle. Livestock Production Science 1, 151-164.

Kay M and Macdearmid A 1973. A note on the effects of changing the concentration of protein in the diets offered to fattening beef cattle. Animal Production 16, 205-207.

Kempster AJ, Cuthbertson A and Harrington G 1982. Carcass evaluation in livestock breeding, production and marketing. Granada, St Albans.

Kempster AJ, Coog GJ and Southgate FR 1988. Evaluation of British Friesian, Canadian Holstein and beef breed x British Friesian steers slaughtered over a commercial range of fatness from 16 month and 24 month beef production systems. 2. Carcass characteristics, and rate and efficiency of lean gain. Animal Production 46, 365-378.

MacRae JC and Armstrong DG 1968. Enzyme method for determination of alpha-linked glucose polymers in biological materials. Journal of the Science of Food and Agriculture 19, 578-581.

Ministry of Agriculture, Fisheries and Food 1982. The feedingstuffs (sampling and analysis), regulatory instrument no. 1144. HMSO, London, UK.
Ministry of Agriculture, Fisheries and Food 1986. The analysis of agricultural materials. MAFF reference book 427. HMSO, London, UK.

Ministry of Agriculture, Fisheries and Food 1993. Prediction of the energy values of compound feedingstuffs for farm animals. MAFF Publications, London, UK.

Newbold JR, Garnsworthy PC, Buttery PJ, Cole DJA and Haresign W 1990. Protein nutrition of growing cattle: food intake and growth responses to rumen degradable protein and undegradable protein. Animal Production 45, 383-394.

Ørskov ER and Mehrez AZ 1977. Estimation and extent of protein degradation from basal feeds in the rumen of sheep. Proceedings of the Nutrition Society 36, A78.

Simm G 1998. Genetic improvement of cattle and sheep. Farming Press, Miller Freeman, Ipswich, UK.

Thomas C, Wilkinson JM and Tayler JC 1975. The utilisation of maize silage for intensive beef production. I. The effect of level and source of supplementary nitrogen on the utilisation of maize silage by cattle of different ages. Journal of Agricultural Science, Cambridge 84, 365-372.

Tomlinson DI, James RE, Bethard GL and McGilliard ML 1997. Influence of undegradability of protein in the diet on intake, daily gain, feed efficiency, and body composition of Holstein heifers. Journal of Dairy Science 80, 943-948.

Wilkinson JM, Lonsdale CR and Tayler JC 1973. The growth of beef cattle fed on maize silage supplemented with dried Lucerne, fishmeal or urea. Journal of the British Grassland Society 28, 13-19. 